\title{
TNJAUAN YURDIS TENTANG PERJANJIAN JUAL-BELI DENGAN SISTEM ONLINE
}

\author{
Oleh \\ Dhevi Nayasari Sastradinata \\ Dosen Fakultas Hukum Universitas Islam Lamongan
}

\begin{abstract}
Abstrak
Diera globalisasi tingkat kebutuhan barang dan jasa semakin meningkat dari segi kualitas maupun kuantitas, hal ini seiring dengan perkembangan dan kemajuan jaman. Teknologi internet dan dunia online juga sudah merambah untuk dapat memenuhi kebutuhan masyarakat secara cepat dan mudah. Mudahnya akses internet dimasyarakat sekarang ini menjadi pemicu banyaknya inovasi website yang menawarkan segala macam jual beli dan transaksi online.Dilihat dari perkembangannya, masyarakat bisa saja merasa diuntungkan atau dapat juga merasa dirugikan. Diuntungkan apabila pemenuhan barang tersebut sesuai dengan permintaan konsumen. Konsumen merasa dirugikan apabila barang yang dibeli oleh konsumen ternyata memiliki kecacatan. Hal ini yang sering ditemui antara pelaku usaha dan konsumen. Sehingga diperlukan peraturan yang tepat agar tidak ada yang dirugikan dalam jual beli online, kendala hukum yang sering terjadi adalah penipuan terhadap konsumen sedangkan kendala non hukum yang sering terjadi adalah ketidaksesuaian barang dengan gambar yang di pesan dalam jual beli online.

Penelitian yang digunakan penulisan adalah pendekatan secara Yuridis Normatif yaitu sebagaiusaha mendekatkan masalah yang diteliti dengan sifat hukum yangnormatif.
\end{abstract}

Kata Kunci : Tinjauan Yuridis, Sistem Online.

\section{PENDAHULUAN}

\section{Latar belakang Masalah}

Diera globalisasi tingkat kebutuhan barang dan jasa semakin meningkat dari segi kualitas maupun kuantitas, hal ini seiring dengan perkembangan dan kemajuan jaman. Teknologi internet dan dunia online juga sudah merambah untuk dapat memenuhi kebutuhan masyarakat secara cepat dan mudah. Mudahnya akses internet dimasyarakat sekarang ini menjadi pemicu banyaknya inovasi webside yang menawarkan segala macam jual beli dan transaksi online. Situs-situs jejaring social yang banyak diminati masyarakat untuk sharing juga mempermudah masyarakat untuk mendapatkan informasi melalui internet.

1. Seiring perkembangan teknologi internet dan online juga berpengaruh terhadap perilaku masyarakat yang cenderung menjadikan media internet dan online sebagai media untuk memperoleh segala informasi secara cepat dan mudah.Baik ituinformasi berita atau komunikasi, internet juga sering digunakan untuk mempromosikan barang dan jasa yang dijual oleh suatu perusahaan atau perorangan. Media internet juga mempermudah konsumen untuk memperoleh informasi akan barang dan jasa yang dibutuhkan oleh konsumen secara cepat dan mudah. Karena dengan cukup melalui internet, konsumen atau masyarakat bisa tahu barang atau jasayang dibutuhkan tanpa harus datang ke tempat atau toko langsung. Transaksi bisa dilakukan dengan cara dari jarak jauh dengan cara konsumen mentransfer uang kemudian produsen mengirimkan produk atau jasa yang diinginkan. Maka terjadilah proses jualbeli melalui media internet 
sesuai ketentuan. Seiring berkembangnya dunia internet di indonesia dan oleh masyarakat Indonesia sering juga disalah gunakan oleh pihak - pihak masyarakat secara negative. Misalnya situs- situs yang dilarang atau porno dan juga berbagai modus penipuan melalui internet yang melanggar hukum.

2. Apabila masyarakat atau konsumen mengalami ketidakadilan yang dilakukan oleh pelaku usaha, konsumen memiliki hak untuk mendapatkan perlindungan hukum guna melindungi hak-hak yang dimilikinya sebagai konsumen. Undang-undang No. 08 tahun 1999 Tentang Perlindungan Konsumen yang disingkat menjadi UUPK pada Pasal 1 angka (1), menyebutkan bahwa "Segala upaya yang menjamin adanya kepastian hukum untuk memberi perlindungan kepada konsumen". Dengan adanya UUPK tersebut, masyarakat memiliki payung hukum untuk melindungi haknya.

3. Dilihat dari perkembangannya, masyarakat bisa saja merasa diuntungkan atau dapat juga merasa dirugikan. Diuntungkan apabila pemenuhan barang tersebut sesuai dengan permintaan konsumen. Konsumen merasa dirugikan apabila barang yang dibeli oleh konsumen ternyata memiliki kecacatan. Hal ini yang sering ditemui antara pelaku usaha dan konsumen.

\section{HASIL PENELITIAN DAN PEMBAHASAN}

\section{Proses Jual Beli Dengan Sistem Online MenurutHukum Yang Berlaku Di Indonesia}

Jual-beli adalah suatu perjanjian dimana pihak yang satu menyanggupi akan menyerahkan hak milik atas suatu barang,sedangkan pihak lainya menyanggupi akan membayar sejumlah uang sebagai harganya. ${ }^{8}$ untuk terjadinya perjanjian ini, cukup jika kedua belah pihak sudah mencapai persetujuan tentang

\footnotetext{
Subekti,pokok-pokok hukum

Perdata,PT.Itermasa HIm 161-162
}

barang dan harganya. Untuk sahnya suatu perjanjian diperlukan empat syarat menurut pasal 1320 Kitab UndangUndang Hukum Perdata :

a. Sepakat mereka yang mengikatkan dirinya artinya para pihak yang membuat perjanjian telah sepakat atau setuju mengenai hal-hal pokok atau materi yang diperjanjikan. Dan kesepakatan itu dianggap tidak ada apabila diberikan karena kekeliruan, kekhilafan, paksaan ataupun penipuan.

b. Cakap untuk membuat suatu perjanjian artinya kecakapan yang dimaksud dalam hal ini adalah bahwa para pihak telah dinyatakan dewasa oleh hukum, yakni sesuai dengan ketentuan KUHPerdata,mereka yang telah berusia 21 (dua puluh satu) tahun, sudah atau pernah menikah. Cakap juga berarti orang yang sudah dewasa, sehat akal pikiran, dan tidak dilarang oleh suatu peraturan perundangundangan untuk melakukan suatu perbuatan tertentu. Di dalam Undang-Undang No. 30 tahun 2004 tentang Jabatan Notaris juga mengatur tentang kecakapan seseorang untuk melakukan perbuatan hukum yakni paling sedikit berumur 18 (delapan belas) tahun, hal ini terdapat dalam pasal 39 UndangUndang Jabatan Notaris. Batas kedewasaan umur seseorang untuk bisa cakap melakukan perbuatan hukum tidak hanya diatur di dalam KUHPerdata dan Undang-undang Jabatan Notaris, dalam Undang-Undang Perlindungan Anak juga mengaturnya, hal ini tertuang dalam pasal 1 ayat 1 yakni Anak adalah seseorang yang belum berusia 18 (delapan belas) tahun, termasuk anak yang masih dalam kandungan. Jadi sudah jelas bawha anak yang berumur 18 (delapan belas) tahun atau lebih bisa dikatakan dewasa dan cakap untuk melakukan perbuatan hukum sesuai dengan peraturan yang berlaku.

c. Mengenai suatu hal tertentu artinya dalam membuat perjanjian, apa

yang diperjanjikan harus jelas sehingga hak dan kewajiban para pihakbisa ditetapkan. 
d. Suatu sebab kausa yang diperbolehkan artinya suatu perjanjian harus berdasarkan sebab yang halal yang tidak bertentangan dengan ketentuan Pasal 1337 Kitab Undang-undang Hukum Perdata, yaitu tidak bertentangan dengan ketertiban umum, tidak bertentangan dengan kesusilaan dan tidak bertentangan dengan Undang-Undang.

Batalnya suatu perjanjian yaitu suatu perjanjian yang dibuatdengan tidak memenuhi syarat sahnya perjanjian yakni Pasal 1320KUHPerdata, hal ini bisa berakibat kepada batalnya perjanjian. Dalamhukum perjanjian ada tiga sebab yang membuat perizinan tidak bebas,yaitu Paksaan adalah terjadi jika seseoarang memberikan persetujuannya karena ia takut pada suatu ancaman. Misalnya salah satu pihak karena diancam dan ditakuttakuti terpaksa menyetujui suatu perjanjian

a. Kekhilafan atau kekeliruan adalah apabila salah satu pihak khilaf tentang halhal yang pokok dari apa yang diperjanjikan atau tentang sifat-sifat yang penting dari barang yang menjadi obyek perjanjian, ataupun mengenai orang dengan siapa diadakan perjanjian itu.Misalnya khilaf mengenai barang, seseorang membeli sebuah lukisan yang dikiranya lukisan Basuki Abdullah tetapi kemudian hanya turunan saja. Khilaf mengenai orang, seorang Direktur Opera mengadakan suatu kontrak dengan orang yang dikiranya seorang

penyanyi yang tersohor, padahal itu bukan orang yang dimaksudkanhanya nama-namanya saja yang kebetulan sama.

b. Penipuan adalah apabila satu pihak dengan sengaja memberikan keteranganketerangan yang palsu atau tidak benar disertai dengan tipu muslihat untuk membujuk pihak lawannya memberikan perizinannya.Misalnya mobil yang ditawarkan diganti dulu mereknya, dipalsukan nomor mesinnya.Dengan demikian, maka ketidakcakapan seseorang dan ketidakbebasan dalam memberikan perizinan pada suatu perjanjian, memberikan hak kepada pihak yang tidak cakap dan pihak yang tidak bebas dalam memberikan sepakatnya itu untuk meminta pembatalan perjanjiannya.

\section{Perlindungan Konsumen Dalam Jual Beli Online Menurut Undang-Undang Yang Berlaku}

Perlindungan Konsumen diatur dalam Undang-Undang Nomor 8 Tahun 1999 pasal 1 angka 1 yang berbunyi "Perlindungan Konsumen adalah segala upaya yang menjamin adanya kepastian hukum untuk memberi perlindungan kepada Konsumen." Rumusan pengertian perlindungan Konsumen yang terdapat dalam pasal tersebut, cukup memadai. Kalimat yang menyatakan "segala upaya yang menjamin adanya kepastian hukum", diharapkan sebagai benteng untuk meniadakan tindakan sewenang-wenang yang merugikan pelaku usaha hanya demi untuk kepentingan perlindungan Konsumen, begitu pula sebaliknya menjamin kepastian hukum bagi konsumen. Setiap orang, pada suatu waktu, dalam posisi tunggal/sendiri maupun berkelompok bersama orang lain, dalam keadaan apapun pasti menjadi Konsumen untuk suatu produk barang atau jasa tertentu. Keadaan universal ini pada beberapa sisi menunjukkan adanya kelemahan, pada Konsumen sehingga Konsumen tidak mempunyai kedudukan yang "aman". Oleh karena itu secara mendasar Konsumen juga membutuhkan perlindungan hukum yang sifatnya universal juga. Mengingat lemahnya kedudukan Konsumen pada umumnya dibandingkan dengan kedudukan produsen yang relatif lebih kuat dalam banyak hal misalnya dari segi ekonomi maupun pengetahuan mengingat produsen lah yang memperoduksi barang sedangkan konsumen hanya membeli produk yang telah tersedia dipasaran, maka pembahasan perlindungan Konsumen akan selalu terasa aktual dan selalu penting untuk dikaji ulang serta masalah perlindungan 
konsumen ini terjadi di dalam kehidupan sehari-hari.

Perlindugan terhadap Konsumen dipandang secara materiil maupun formiil makin terasa sangat penting, mengingat makin lajunnya ilmu pengetahuan dan teknologi yang merupakan motor penggerak bagi produktifitas dan efisiensi produsen atas barang atau jasa yang dihasilkannya dalam rangka mencapai sasaran usaha. Dalam rangka mengejar dan mencapai kedua hal tersebut, akhirnya baik langsung atau tidak langsung, maka Konsumenlah yang pada umumnya merasakan dampaknya.

hak-hak konsumen bisa dilihat di Pasal 4 UU PK, antara lain:

a. hak atas kenyamanan, keamanan, dan keselamatan dalam mengkonsumsi barang dan/atau jasa;

b. hak untuk memilih barang dan/atau jasa serta mendapatkan barang dan/atau jasa tersebut sesuai dengan nilai tukar dan kondisi serta jaminan yang dijanjikan;

c. hak atas informasi yang benar, jelas, dan jujur mengenai kondisi dan jaminan barang dan/atau jasa;

d. hak untuk didengar pendapat dan keluhannya atas barang dan/atau jasa yang digunakan;

e. hak untuk mendapatkan advokasi, perlindungan, dan upaya penyelesaian sengketa perlindungan konsumen secara patut;

f. hak untuk mendapat pembinaan dan pendidikan konsumen;

g. hak unduk diperlakukan atau dilayani secara benar dan jujur serta tidak diskriminatif;

h. hak untuk mendapatkan kompensasi, ganti rugi dan/atau penggantian, apabila barang dan/atau jasa yang diterima tidak sesuai dengan perjanjian atau tidak sebagaimana mestinya; hak-hak yang diatur dalam ketentuan peraturan perundangundangan lainnya. ${ }^{9}$

\footnotetext{
${ }^{9}$ http://www.landanteori.com/2015/09/pengertianperlindungan-konsumen.html
}

Sedangkan kewajiban konsumen diatur dalam Pasal 5 UUPK, yaitu:

a.Membaca atau mengikuti petunjuk informasi dan prosedur pemakaian atau pemanfaatan barang dan/atau jasa demi keamanan dan keselamatan

b.Beritikad baik dalam melakukan transaksi pembelian barang /atau jasa

c.Membayar sesuai dengan nilai tukar yang disepakati

d.Mengikuti upaya penyelesaian hukum sengketa perlindungan konsumen secara patut

Pasal 6 dan Pasal $7 \quad$ UU Perlindungan Konsumen. dapun hak dan kewajiban Pelaku Usaha adalah sebagai berikut:

Hak pelaku usaha adalah:

- hak untuk menerima pembayaran yang sesuai dengan kesepakatan mengenai kondisi dan nilai tukar barang dan/atau jasa yang diperdagangkan;

- hak untuk mendapat perlindungan hukum dari tindakan konsumen yang beritikad tidak baik;

- hak untuk melakukan pembelaan diri sepatutnya di dalam penyelesaian hukum sengketa hak untuk rehabilitasi nama baik apabila terbukti secara hukum bahwa kerugian konsumen tidak diakibatkan oleh barang dan/atau jasa yang diperdagangkan;

- hak-hak yang diatur dalam ketentuan peraturan perundang-undangan lainnya.

Kewajiban pelaku usaha adalah:

- beritikad baik dalam melakukan kegiatan usahanya;

- memberikan informasi yang benar, jelas dan jujur mengenai kondisi dan jaminan barang dan/atau jasa serta memberi penjelasan penggunaan, perbaikan dan pemeliharaan;

- memperlakukan atau melayani konsumen secara benar dan jujur serta tidak diskriminatif;

- menjamin mutu barang dan/atau jasa yang diproduksi dan/atau 
diperdagangkan berdasarkan ketentuan standar mutu barang dan/atau jasa yang berlaku;

- memberi kesempatan kepada konsumen untuk menguji, dan/atau mencoba barang dan/atau jasa tertentu serta memberi jaminan dan/atau garansi atas barang yang dibuat dan/atau yang diperdagangkan;

- memberi kompensasi, gantirugi dan/atau penggantian atas kerugian akibat penggunaan, pemakaian dan pemanfaatan barang dan/atau jasa yang diperdagangkan;

- memberi kompensasi, ganti rugi dan/atau penggantian apabila barang dan/atau jasa yang diterima atau dimanfaatkan tidak sesuai dengan perjanjian.

1.Poin-Poin Perubahan UU Perlindungan Konsumen

- Mekanisme penyelesaian sengketa konsumen termasuk yang akan ditata. Mengakomodasi kemungkinan sengketa dalam jual beli ONLINE

- Kementerian Perdagangan sedang mempersiapkan revisi UU No. 8 Tahun 1999 tentang Perlindungan Konsumen (UUPK). Sudah 15 tahun Undang-Undang ini dijalankan, dan bolong-bolongnya sudah kelihatan. UUPK lahir saat Indonesia baru saja menghadapi hantaman krisis moneter, dan menjadi salah satu prasyarat yang diajukan Dana Moneter Internasional (IMF) agar Indonesia diberi bantuan. Karena itu, saat dilakukan revisi.

Gagasan revisi itu antara lain dikemukakan Yohanes Gunawan. Guru Besar Fakultas Hukum Universitas Parahyangan Bandung, ini berpendapat sudah saatnya UUPK direvisi sebab selama lima belas tahun berjalan penegakan hukum perlindungan konsumen masih menghadapi kendala. Salah satu penyebabnya UUPK punya kelemahan, kekurangan atau kekeliruan. ${ }^{10}$

Kekeliruan, kekurangan dan kelemahan pengaturan dalam UUPK, kata Yohanes, bisa dilihat dari aspek gramatika,

\footnotetext{
${ }^{10} \mathrm{https} / / / \mathrm{www}$. prayogoadvocaten.com/news/detail/3 4/apa/saja-hak-dan-kewajiban-pelaku-usaha
}

sistematika, tanggung jawab pelaku usaha, penyelesaian sengketa konsumen, dan kelembagaan. "UUPK harus dicabut dan dibentuk Undang-Undang baru karena UUPK dirancang dengan amat tergesagesa," kata Yohanes dalam diskusi di Kantor Kementerian Perdagangan Jakarta, Selasa (24/11).

- Sebagai pihak yang ikut menyusun naskah akademik perubahan UUPK sejak 2007, Yohanes mencatat setidaknya ada empat perubahan substansi dalam UUPK. Pertama, hak dan kewajiban konsumen dan pelaku usaha/penyedia jasa. Dalam naskah akademik, terdapat klausula bahwa negara memiliki kewajiban untuk melindungi konsumen, penggantian istilah pelaku usaha jasa menjadi penyedia/pemasok jasa, rincian barang/jasa yang dibagi menjadi bergerak dan tidak bergerak, serta beraga/berwujud untuk barang, dan profesional atau komersial untuk jasa.

Naskah akademik juga memuat pemisahan hak dan kewajiban konsumen dan pelaku usaha/penyedia jasa, terutama hak dan kewajiban konsumen dan penyedia jasa. Jasa profesional wajib memiliki kode etik, sementara jasa komersial yang bertujuan untuk mencari laba tidak diwajibkan memiliki kode etik.

- Kedua, perubahan UUPK harus menjelaskan secara rinci tanggung jawab pelaku usaha barang dan jasa.

- Ketiga, perjanjian baku dan klausula baku. Menurut Johanes, seiring berkembangnya waktu, bentuk kontrak pun turut berkembang. Saat ini dikenal tiga kontrak yakni negotiated contract, standardizedcontract, dan digital contract. Namun kontrak yang dilakukan dalam jual beli dengan sistem omlinejustru belum melindungi konsumen. Ia sepakat untuk membentuk cross border resolution dalam UUPK terutama untuk transaksi yang dilakukan secara online. "Misalnya membeli sebuah produk di sebuah situs online seperti Lazada. Digital contract atau e-commerce, hukum yang berlaku apakah dari penjual atau pembeli? Ini belum ada 
aturannya, choice of lawbelum ada, apalagi choice of forum. Maka harus diatur ecommerce ini dalam UUPK," jelasnya.

- Keempat, mengenai penyelesaian sengketa konsumen atau kelembagaan perlindungan konsumen. Pasal 23 UUPK menjelaskan sengketa konsumen dapat diselesaikan melalui dua cara yakni pengadilan dan luar pengadilan. UUPK menyebutkan putusan yang diselesaikan melalui jalur non litigasi atau BPSK adalah final dan mengikat. Kemudian atas putusan tersebut, ada pihak-pihak yang mengajukan keberatan melalui pengadilan. Yohanes menyebut alur penyelesaian semacam itu keliru.

- Dalam revisi UUPK, putusan BPSK final dan mengikat. Pelaku usaha wajib melaksanakan putusan dalam waktu tujuh hari kerja. Jika tidak, maka BPSK dipersilahkan untuk menyerahkan putusan kepada penyidik sesuai hukum acara pidana. Guna memperkuat posisi BPKN, Yohanes mengusulkan BPKN merupakan badan yang dibentuk oleh Presiden untuk memberikan usul, melakukan evaluasi dan pengawasan negara untuk menjamin konsumen memperoleh perlindungan. Pemerintah pun wajib memberikan tanggapan atas usul, hasil evaluasi, dan hasil pengawasan BPKN, dan badan ini harus mengumumkan hasil evaluasi, usul, dan hasil pengawasan tersebut kepada masyarakat. Sementara untuk usul kelembagaan perlindungan konsumen terdiri dari pemerintah dan pemerintah daerah, BPKN, BPSK, Badan Peradilan Umum, Lembaga Perlindungan Konsumen Swadaya Masyarakat (LPKSM), Perhimpunan/Perkumpulan/Kelompok

Konsumen, dan asosiasi pelaku usaha. Ekonom Senior Australia Indonesia Partnership for EconomicGovernance Ahmad Sauqi menilai upaya perlindungan konsumen di Indonesia belum optimal. Pasalnya, UU PK sebagai dasar hukum perlindungan konsumen masih memiliki banyak kelemahan. Institusi pelaksana masih lemah, belum menjadi bagian utama dalam kebijakan ekonomi dan konsumen yang belum berdaya.

- Menurut Sauqi, keberhasilan perlindungan konsumen ditentukan oleh tiga hal. Pertama, kerangka kebijakan yang efektif, konsumen yang berdaya, dan kebijakan persaingan yang efektif. UUPK saat ini masih memiliki banyak kelemahan dalam gramatika dan sistematika materi, tidak memadai lagi dengan kemajuan ITC, dan kelemahan dalam pengaturan lembaga. "Sementara untuk materi perlindungan konsumen dalam UUPK sudah cukup komprehensif," kata Sauqi dalam diskusi yang sama.

Sauqi mengatakan fungsi BPKN hanya sekadar memberikan saran dan pertimbangan kepada pemerintah. Karena itu ia berharap cakupan tugas BPKN perlu diperluas, struktur organisasi harus optimal, sumber daya semakin ditingkatkan, dan harus masuk dalam mekanisme penyusunan kebijakan. Mengenai BPSK, Sauqi lebih melihat persoalan kapasitas yang rendah dan timpang antar wilayah. Sumber daya daerah belum memadai untuk mendukung BPSK, dan ketidakpastian komitmen pemerintah daerah dan sumber daya yang sangat terbatas. Masalah tersebut membuat BPSK menjadi tidak optimal

- $\quad$ Sehingga, lanjut Sauqi, perlu adanya pemberdayaan konsumen yang dilakukan oleh pemerintah dan LPKSM. Kebijakan persaingan guna melindungi konsumen, dan menyusun strategi nasional perlindungan konsumen. Salah satu caranya, reformasi penyelesaian sengketa konsumen. Langkah berikutnya adalah kebijakan persaingan. Sauqi berpendapat Pemerintah harus melakukan sinkronisasi kebijakan ekonomi dan kebijakan persaingan, pengarusutamaan kebijakan persaingan, dan kebijakan yang tepat untuk pengembangan industri dalam negeri agar kepentingan konsumen tidak dikorbankan. $^{11}$ Koordinator Harian

\footnotetext{
${ }^{11}$ http://www.hukumonline.com/berita/baca/lt56542 070106f4/inilah-poin-poin-perubahan-uuperlindungan-konsumen
} 
Yayasan Lembaga Konsumen Indonesia (YLKI) Sudaryatmo menyampaikan bahwa sudah sepatutnya hak konsumen dimasukkan ke dalam UUD 1945. Selain itu, keberadaan lembaga konsumen lebih tepat berada di bawah Bappenas. "Di negara lain, persoalan perlindungan konsumen itu erat hubungannya dengan aspek legal. Maka sebaiknya isu perlindungan konsumen di Indonesia juga dilakukan demikian," pungkasnya.

\section{KESIMPULAN}

1. Sistem perjanjian jual beli online hukum perdata di Indonesia, jual beli diatur dalam buku III KUH-Perdata tentang perikatan. Jual beli terjadi karena adanya suatu kesepakatan antara para pihak. Kesepakatan itu diwujudkan dalam suatu perjanjian yang menjadi dasar perikatan bagi

pihak-pihak tersebut. Aspek hukum perjanjian jual beli online dapat memiliki kekuatan hukum berdasarkan asas kebebasan berkontrak sebagaimana diatur dalam Pasal 1338 ayat (1) KUH-Perdata tentang kebebasan berkontrak. Kepastian hukum perjanjian jual beli Online ditinjau dari perlindungan hukum positif yaitu Undang-Undang Nomor 11 tahun 2008, Peraturan Pemerintah Nomor 82 Tahun 2102, KUH-Perdata transaksi elektronik yaitu pasal 40-51, Pelaksanaan atau proses kontrak

2.Perlindungan hukum terhadap konsumen dalam transaksi jual beli dengan sistem onlineyang timbul dari adanya hak dan kewajiban dari kedu belah pihak yang diatur dalam Undang-Undang Nomor 8 tahun 1999 terdapat dalam Pasal 4 ayat (3) dan pada pasal 4 ayat (6) "hak untuk mendapat pembinaan dan pendidikan konsumen" kewajiban pelaku usaha harus didasari oleh Pasal 7 Undang-Undang Nomor 8Tahun 1999 tentang Perlindungan Konsumen.

\section{Saran}

1. Para pihak baik pelaku usaha dan konsumen yang menggunakan jasa jual beli dengan sistem online dituntut untuk menerapkan asas kehati-hatian dan melakukan pemeriksaan terhdap penjual dan pembeli yang melakukan jual beli dengan sitem online serta perlu adanya sosialisasi pemerintah terkait cara bertransaksi jual beli dengan sistem online dengan aman sehingga masyarakat dapat memahami dan mengetahui serta melaksanakan transasksi jual-beli dengan sistem online sesuai dengan aturan yang berelaku dan dengan pembuatan UndangUndang yang mengatur penuh perlindungan konsumen,karena selama ini hukum yang mengatur perlindungan konsumen terpencar kemana-mana seperti Undang-Undang Nomor 8 Tahun 1999 tentang Perlindungan Konsumen, KUH Perdata. KUH Pidana, Hukum Internasional, dan lain-lain.

\section{DAFTAR PUSTAKA}

\section{Literatur}

Subekti. 2003 Pokok-Pokok Hukum Perdata. Jakarta: intermasa.

Suharnoko. 2004 Hukum Perjanjian: Teori dan Analisa Kasus,Jakarta: kencana

\section{Perundang-undangan}

Undang-Undang R. I Nomor 8 Tahun 1999 Tentang Perlindungan Konsumen

Undang-Undang Informasi \& Transaksi Elektronik

\footnotetext{
Artikel

LinggarErySusanto,Perlindungankonsumen,w ww.scribd.com

Paskah Wartono Kristanto,Perkembangan Ecommerce di Indonesia dan di

Dunia,2012,http://blog.ub.ac.id

Triyono Setyo,Perkembangan e-comemerce di Indonesia,2012,www.unpas.ac.id http://www.landanteori.com/2015/09/pengertia n-perlindungan-konsumen.html https://www.prayogoadvocaten.com/news/deta il/34/apa/saja-hak-dan-kewajiban-pelaku-usaha http://www.hukumonline.com/berita/baca/lt56 542070106f4/inilah-poin-poin-perubahan-uuperlindungan-konsumen
} 